\title{
Long term pasture growth patterns for Southland New Zealand: 1978 to 2012
}

\author{
L. C. SMITH \\ AgResearch, Woodlands Research Station, RD, Invercargill, New Zealand \\ chris.smith@agresearch.co.nz
}

\begin{abstract}
Pasture growth rates for Southland were reported by several researchers in the late 1970s and early 1980s. However, pasture species and farm management systems have changed somewhat since then. This paper presents data from measurements at Woodlands, near Invercargill, that have been ongoing since 1977, and discusses some of the variability that has occurred over the years. Measurement of pasture growth was done using a standardised cutting method known as "rate of growth" or moving cages, with measurements every 3 weeks. Annual yields were calculated from 1 June to 31 May of the next year. The pasture growth at Woodlands is characterised by a spring-summer peak of growth followed by a deep winter trough where growth is minimal. Long-term average annual growth was $11.8 \mathrm{t}$ $\mathrm{DM} /$ ha for older 'Ruanui' based pasture and $12.7 \mathrm{t} \mathrm{DM} /$ ha for newer 'Nui'/'Supreme'/‘Greenstone' ryegrass based pasture. However the newer pasture produced considerably more ( $c a .14 .2 \mathrm{t} \mathrm{DM} / \mathrm{ha} /$ year) for an initial period of 3 years, after which time the production dropped back to be similar to the old pasture $(c a .12 .0 \mathrm{t}$ $\mathrm{DM} / \mathrm{ha} /$ year).
\end{abstract}

Key words. pasture growth; long-term; annual variability

\section{Introduction}

Southland is an intensive pastoral farming region which relies on consistent pasture production to maintain high animal productivity, in both sheep and dairying systems. It is a region where there is a large seasonal variation in yield from minimal production over winter to production in excess of animal requirements in late November/December. Pasture growth data were reported by Harris et al. (1973), Radcliffe (1974b) and Cossens (1990) who presented data from up to 11 years of pasture measurements between 1950 and 1987. Since then, farming in Southland has both intensified and seen changes in management systems. In the late 1970s allgrass farming became popular and this resulted in less pasture renewal than had previously occurred following winter forage cropping (Hook 1978). During the 1980s fertiliser inputs also declined as a result of financial and other pressures (Quin \& Scobie 1985). Despite these factors, new pasture cultivars with improved production characteristics continued to be developed (Widdup \& Ryan 1992).

Seasonal variation between years and seasons within years can be a major influence on farm management decisions. Radcliffe (1974b) showed that annual pasture production can vary by as much as $33 \%$. Hutchinson et al. (2000), in analysing the data from the Topoclimate ${ }^{\mathrm{TM}}$ survey of Southland, suggested that temperature was one of the driving forces for average pasture production, though it could not account for annual variation, as other environmental factors such as moisture availability could override it. However, Smith et al. (2012a) showed that even for irrigated pastures where moisture was likely to be less of a limiting factor, such annual variation still occurred. Other workers have suggested that temperature and plant phenology greatly influence pasture production (Li et al. 2011), while Roche et al. (2009) found moderate correlations between solar radiation and pasture growth rates after correcting for time of year. This paper presents data from 35 years of pasture growth rate measurements at Woodlands and highlights some of the variability in annual and seasonal pasture growth that can occur.

\section{Methods}

Site

The site is situated on the Woodlands Research Station $15 \mathrm{~km}$ east of Invercargill, Southland, New Zealand $\left(46^{\circ} 22^{\prime} \mathrm{S}, 168^{\circ} 35^{\prime} \mathrm{E}\right)$. The soil type is a Waikiwi silt loam (Bruce 1977) classified as a Typic firm brown soil (Hewitt 1998). At the commencement of the measurements in late 1977, the pasture was approximately 8 years old and consisted primarily of perennial ryegrass (Lolium perenne) and white clover (Trifolium repens), with some other grass species, mainly poa (Poa sp.), browntop (Agrostis tenuis) and crested dogstail (Cynosurus cristatus L.) also present. The pasture was rotationally grazed by sheep as part of the normal farm rotation. Typical stocking rates varied from 15 to $19 \mathrm{su} / \mathrm{ha}$. In December 2000 the pasture was renewed by removal of the old pasture with glyphosate at recommended rates followed by direct drilling of 'Nui'/'Supreme'/'Greenstone' ryegrass, together with 'Demand' white clover 
From the commencement of measurement until 1991, the pasture was maintained in a state of soil fertility typical of sheep farms in the district with annual applications of $27-30 \mathrm{~kg} \mathrm{P} / \mathrm{ha}$ as superphosphate together with lime $(2.5 \mathrm{t} / \mathrm{ha})$ applied regularly to maintain soil pH levels between 5.7 and 6.1. From 1991 to 1995 reactive phosphate rock (RPR) at $32 \mathrm{~kg}$ $\mathrm{P} /$ ha was the only fertiliser applied. From 1996 until the present, the fertiliser regime changed to annual applications of $45 \mathrm{~kg} \mathrm{P} / \mathrm{ha}$ as superphosphate together with $500 \mathrm{~kg} / \mathrm{ha}$ lime. This resulted in the soil Olsen $P$ lifting from a low of 12 following several years of RPR application to an average of 27 over the period 1998 to 2011. Although the Olsen P levels following the period of RPR use were lower than considered optimum (Morton \& Roberts 2009) it is known (Perrott et al. 1992) that the Olsen $\mathrm{P}$ test will under-estimate plant available $\mathrm{P}$ after prolonged RPR use.

\section{Measurements}

Pasture growth was measured using a standardised cutting method known as "rate of growth" (Radcliffe 1974a). With this technique four pasture frames (3.3 $\mathrm{m} \times 1.5 \mathrm{~m}$ ) were randomly placed in a paddock, and pasture within the cages was trimmed by a rotary mower to a set height (approx $3 \mathrm{~cm}$ ). Following a set period of 3 weeks ( 6 weeks in winter when growth was low), pasture re-growth in the cages was harvested (to the same mower height) and the cages were moved to a new pre-trimmed area. If there was not enough growth, due to recent grazing, to pre-trim an area outside the cages, then the cages were replaced on the same spot after trimming of any remaining herbage.
Yields were calculated as $\mathrm{kg} \mathrm{DM} / \mathrm{ha}$ for each harvest date, and converted to $\mathrm{kg} \mathrm{DM} / \mathrm{ha} /$ day by dividing by the number of days between trimming and harvesting. Daily growth rates were aligned to a "standard" cutting date with a 14-day interval as defined by Radcliffe (1974a). However, when the harvest date was close to the centre of the interval between these "standard' dates, the growth was pro-rated between the harvest dates. There were two periods when measurements were omitted for a period of several months. The first of these was in 1994 (July - September) while funding was obtained to continue the trial, and the second was while the new pasture was being established (December 2000 - May 2001).

Annual yields were calculated from 1 June each year to 31 May of the next year. The variability of the yields calculated for standard cutting dates have been expressed as a mean of the years \pm standard error (SE).

\section{Climate}

Rainfall and temperature data were measured at the Woodlands Research Station from the commencement of measurement until 1985 and from 1988 until 2008. For the period 1985 to 1988 the data from the nearest meteorological station (Invercargill; $22 \mathrm{~km} \mathrm{SW}$ ) were used.

\section{Results and Discussion}

The climate at Woodlands is typical of most of the eastern and southern Southland plains. It is generally humid and cloudy with evenly distributed rainfall. Average rainfall normally exceeds potential evapotranspiration in all months except February (Table 1). Occasional

Table 1 Rainfall and temperature data (1978-2012) for Woodlands

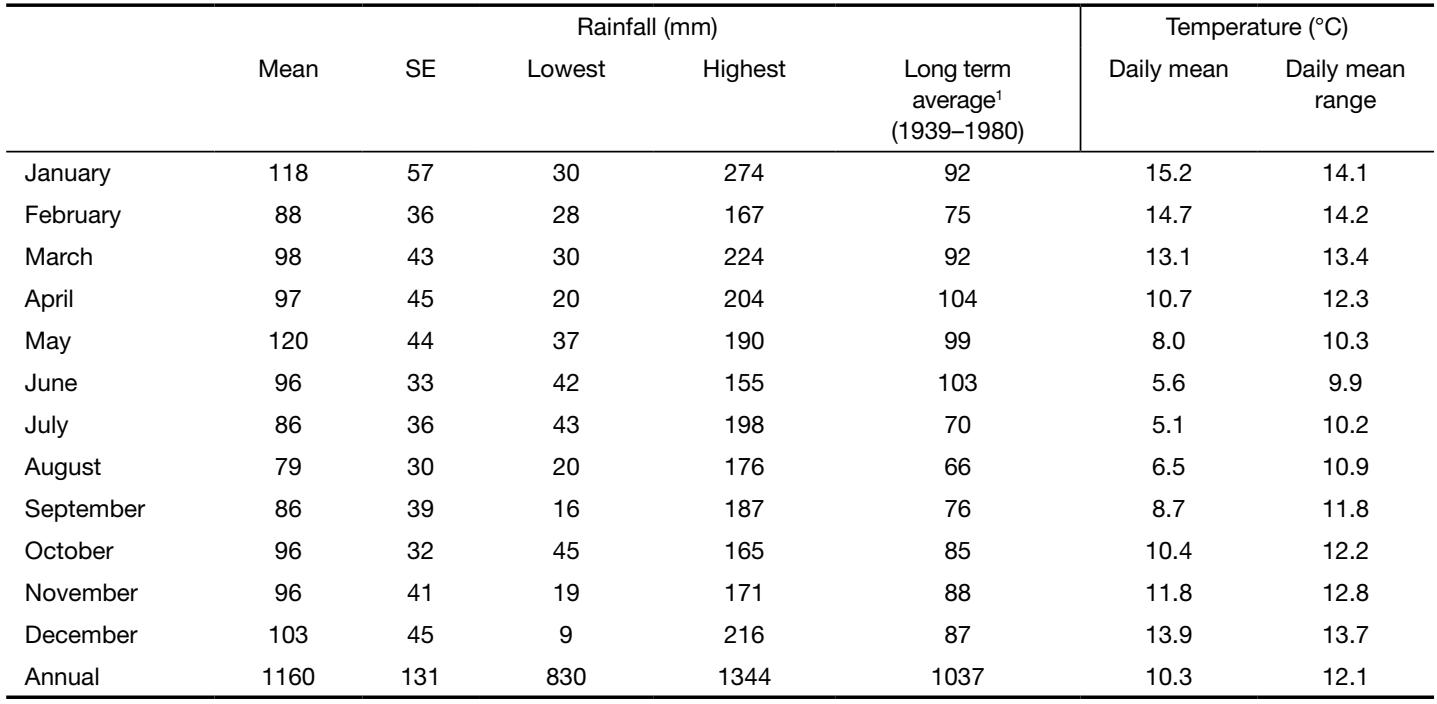

Note: ${ }^{1}$ Long term average taken from Invercargill airport $22 \mathrm{~km} \mathrm{SW}$ of Woodlands 

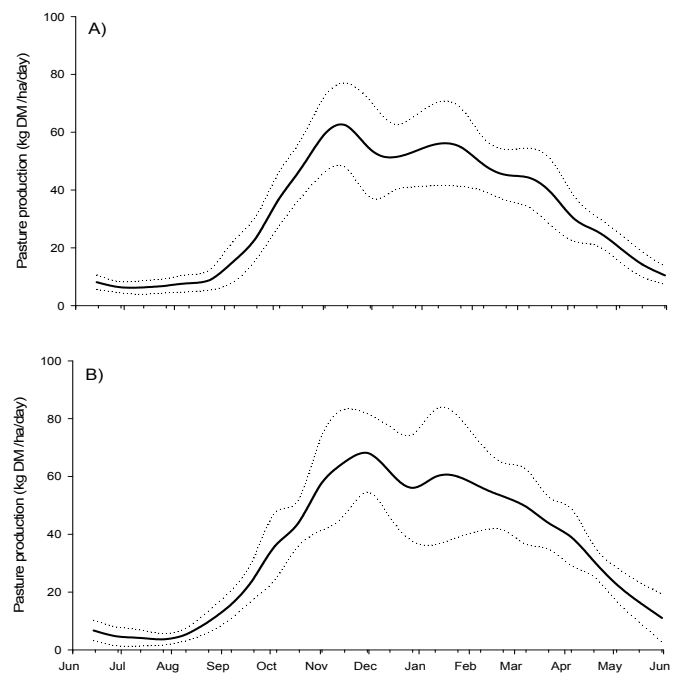

Figure 1. Distribution of pasture growth at Woodlands, Southland for: A) the old 'Ruanui' based pasture (1978-2000) and: B) newer 'Nui'/'Supreme'/‘Greenstone' based pasture (2001-2011). Solid line gives the mean daily growth while the dotted lines give \pm SE

periods of soil water deficit can occur, usually between January and March.

The pasture growth at Woodlands is characterised by a spring-summer peak of growth followed by a deep winter trough where growth is minimal (Fig. 1). This result is in agreement with earlier published growth patterns for Southland (Radcliffe 1974b) measured by this technique. This seasonal growth pattern is one where only $4 \%$ of the annual growth occurs in the winter months while $33 \%$ occurs in the spring, $42 \%$ in the summer and $21 \%$ in the autumn. This pattern has implications for the farmer as it does not match animal requirements, being too low in winter and early spring, and too high in the summer. The excess production over the summer has traditionally been conserved as hay, silage or balage for feeding at times when pasture production is lower than animal demand. The requirement for supplementation over the winter/ spring period has also led to the widespread practice of grazing winter forage crops, particularly for dairy cows following the intensification of the last decade. This practice has implications both for soil structure

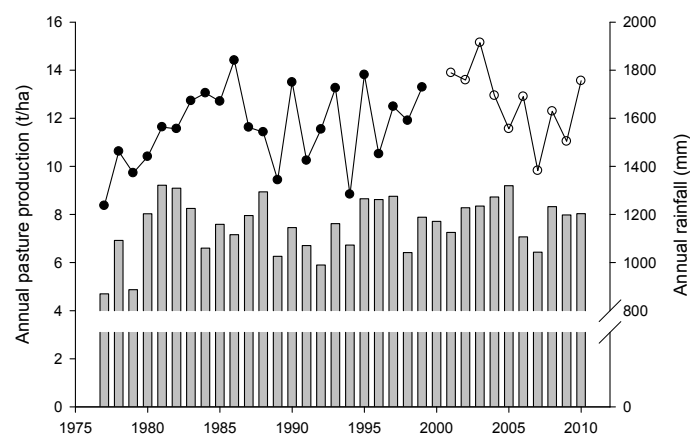

Figure 2. Annual pasture growth (line; t/ha) and rainfall (bars; $\mathrm{mm}$ ) for the period June-May each year: indicates older pasture 1977-2000; $\bigcirc$ indicates newer pasture 2001-2012.

(Drewry \& Paton 2005) and for water quality (Smith et al. 2012b).

From the beginning of measurement in 1977, total annual production increased steadily (Fig. 2) until it reached a peak in 1986/87, following which relatively large annual fluctuations occurred. This pattern is similar to that which occurred at Winchmore where annual production also increased significantly over the 1980-1990 period (Smith et al. 2012a). While the initial increase may have been as a result of increased rainfall or fertility, the reason for the decline and increased variability after 1986/87 is unknown, as there does not appear to be any correlation between the annual production and rainfall for that period (Fig. 2). As suggested by Li et al. (2011), it is likely that temperature and plant phenology also greatly influenced pasture production, though sunlight is probably the more limiting factor as Roche et al. (2009) found moderate correlations between sunlight and pasture growth rates for time-corrected solar radiation. It is possible however that the lower production measured in 1991-1993 may have been partly due to the change to RPR fertiliser in 1991 as Sinclair \& Dyson (1990) suggested that RPR is less effective in increasing dry matter yields than more soluble P fertilisers for at least the first 2 years of use.

Production from the newer pasture (post-2000) was, on average $0.9 \mathrm{t} \mathrm{DM} /$ ha/year $(12.7 \mathrm{v} 11.8 \mathrm{tDM} /$ ha/year $)$ higher than that for the older pasture (Fig. 3). However, if one omits the initial dry period $1977-1980$ then the

Table 2 Seasonal pasture growth (excluding winter 1994; kg DM/ha per 3 months)

\begin{tabular}{lcccc|cccc}
\hline & \multicolumn{3}{c}{ Old pasture (1978-2000) } & \multicolumn{4}{c}{ New pasture (2001-2012) } \\
& Mean & SE & Lowest & Highest & Mean & SE & Lowest & Highest \\
\hline Winter & 748 & 212 & 475 & 1124 & 594 & 221 & 298 & 897 \\
Spring & 4081 & 691 & 2859 & 5630 & 4200 & 658 & 2960 & 5050 \\
Summer & 4625 & 767 & 3345 & 6266 & 5153 & 1129 & 3248 & 7432 \\
Autumn & 2329 & 335 & 1828 & 3014 & 2689 & 435 & 1900 & 3182 \\
\hline
\end{tabular}




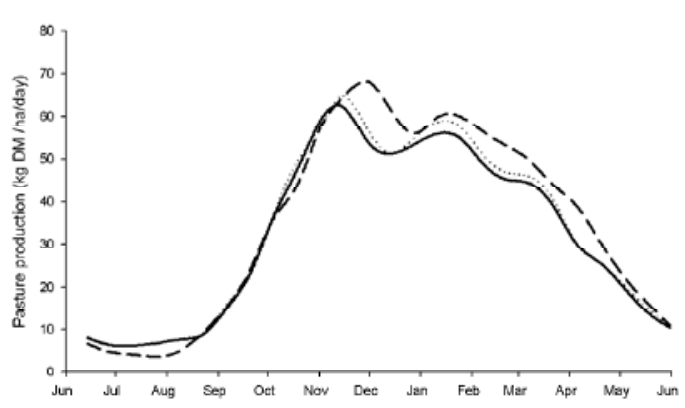

Figure 3. Comparison of pasture growth for old pasture (1988-2000; solid line), newer pasture (2001-2012; dashed line) and omitting initial dry years (19771980; dotted line) for old pasture.

difference is somewhat smaller $(0.7 \mathrm{t} \mathrm{DM} /$ ha; Figure $3)$. The annual variability was similar for both the older and newer pasture (range $=5.0 \mathrm{vs} .5 .3 \mathrm{t} / \mathrm{ha}$; var. $=2.3$ vs 2.4; Fig. 2). The majority of the increased pasture production with the newer pasture cultivars occurred over the summer and autumn months (Fig. 3; Table 3 ), and as such was likely to be surplus to the animals' requirements, unless animal numbers or utilisation were also increased. However extra pasture growth in mid-late autumn is likely to be carried over into winter, where it can be of significant value.

Initially the newer cultivars produced considerably (20\%) more than the older pasture (2001-2004 average $=14.2 \mathrm{t} \mathrm{DM} /$ ha/year; Fig. 4). However production declined after 3 years to be similar to that of the older pasture (2005-2012 average $=12.0 \mathrm{t} \mathrm{DM} / \mathrm{ha} /$ year $)$. The reasons for the new cultivars' increased production only lasting for such a short time are unknown, though some of the lack of performance of the newer pasture in later years can be attributed to climate. Climatic factors appear to have resulted in below normal late spring growth (2009/2010; Fig. 4), poor summer growth (2005/2006 and 2008/2009) or a combination of these (2004/2005). Of particular note are the dry summerearly autumn of 2007/2008 and the dry December of 2011. These dry periods resulted in extended periods of lower than normal growth as was noticeable in the autumn of 2008 and the summer of 2011/2012 (Fig. 4). It would appear that pasture in Southland, once rainfall allows soil moisture levels to increase following an extended dry period, takes a minimum of 2 months to recover to near normal production, assuming that overgrazing of the pasture did not occur during the dry spell. It also appears that the later in the autumn the rains arrive the longer this pasture growth recovery takes, and thus the greater the feed deficit the farmer can expect. The spring feed deficits appear to be mostly due to colder temperatures and lack of sunshine, whereas it is the lack of moisture that drives the summer deficits.

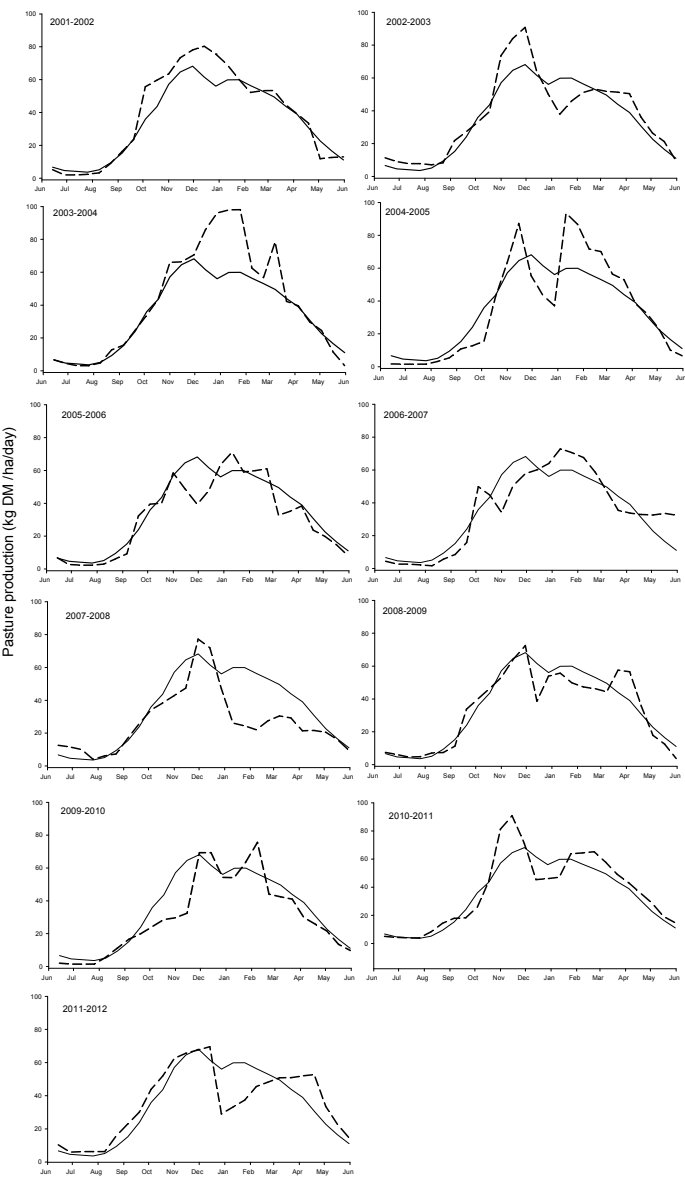

Figure 4. Patterns of pasture growth for individual years (dotted line) compared to the mean (solid line) for the newer pasture (2001-2012).

\section{Conclusion}

Pasture production at Woodlands averaged $11.8 \mathrm{t} \mathrm{DM} /$ ha for older 'Ruanui' based pasture and $12.7 \mathrm{t} \mathrm{DM} /$ ha for newer 'Nui'/'Supreme'/'Greenstone' ryegrassbased pasture. However the newer pasture produced considerably more (14.2 t DM/ha/year) for an initial period of 3 years. The pasture growth is characterised by a spring-summer peak of growth followed by a deep winter trough where growth is minimal. Over the years there have been several times where colder than normal spring weather or extended summer dry periods have resulted in major periods of production falling short of animal requirements. This variability in pasture production can have major implications for the farmer in terms of ongoing management decisions. The information presented here has been made available in real time (monthly) to farmers and industry for in excess of 10 years and as such has allowed timely decisions to be made, so limiting the effects of some of the variability in pasture growth. 


\section{ACKNOWLEDGMENTS}

I would like to thank Bill Risk for initiating the measurements in 1977 as well as Kevin Knowler and the Woodlands farm staff for their assistance with field measurements. I also thank Ballance Agri-Nutrients for their support in funding this work and Tom Fraser for constructive comment on an early draft of this paper.

\section{REFERENCES}

Bruce, J.G. (1977). Soils of Woodlands Research Station, Southland New Zealand. New Zealand Soil Survey Report 32

Cossens, G.G. 1990. Pasture and lucerne production in Otago and Southland 1950 to 1987. Invermay Technical Report no 21.

Drewry, J.J.; Paton, R.J. 2005. Soil physical quality under cattle grazing of a winter fed brassica crop. Australian Journal of Soil Research 43: 525-531.

Harris, A.J.; Brown K.R.; Turner J.D.; Johnston, J.M.; Ryan D.L.; Hickey M.J., 1973. Some factors affecting pasture growth in southland. New Zealand Journal of Experimental Agriculture 1: 136-163.

Hewitt, A. E. 1998 New Zealand soil classification. DSIR Land Resources Scientific Report No. 19.

Hook, P.J. 1978. Recent advances in grassland management in Eastern Southland and West Otago. Proceedings of the New Zealand Grasslands Association 40: 17-24.

Hutchinson, G. K.; Richards K.; Risk, W. H. 2000. Aspects of accumulated heat patterns (growing degreedays) and pasture growth in Southland. Proceedings of the New Zealand Grasslands Association 62: 81-85.

Li, F.Y.; Snow, V.O.; Holzworth, D.P. 2011. Modelling the seasonal and geographical pattern of pasture production in New Zealand. New Zealand Journal of Agricultural Research 54: 331-352.

Morton, J.D.; Roberts, A.H.C. 2009. Fertiliser use on New Zealand sheep and beef farms. New Zealand Fertiliser Manufacturer's Research Association, Auckland, New Zealand. 40p.

Perrott, K.W.; Roberts, A.H.C.; Saggar, S.; Shannon, P.W.; Nguyen, L.; Risk, W.H. 1992. Pasture production and soil phosphorus fractions resulting from six previous applications of triple superphosphate or Sechura phosphate rock. New Zealand Journal of Agricultural Research 35: 307-319.
Quin, B.F.; Scobie, G.M. 1985. Getting them best return from fertiliser expenditure. Proceedings 37th Ruakura Farmers Conference. 42-45.

Radcliffe, J.E. 1974a. Seasonal distribution of pasture production in New Zealand. I. Methods of measurement. New Zealand Journal of Experimental Agriculture 2: 337-340.

Radcliffe, J.E. 1974b. Seasonal distribution of pasture production in New Zealand. II. Southland Plains. New Zealand Journal of Experimental Agriculture. 2: 341-348.

Roche, J.R.; Turner, L.R.; Lee, J.M.; Edmeades, D.C.; Donaghy, D.J.; Macdonald, K.A.; Penno, J.W.; Berry, D.P. 2009. Weather, herbage quality and milk production in pastoral systems. 3. Interrelationships and associations between weather variables and herbage growth rate, quality and mineral concentration. Animal Production Science 49: 211-221.

Sinclair, A.G.; Dyson, C.B. 1990. The long term effectiveness of reactive phosphate rock as a phosphate fertilizer for New Zealand pastures. Proceedings of the New Zealand Grasslands Association 51: 101-104.

Smith, L.C.; Moss, R.; Morton, J.D.; Metherell, A.; Fraser, T. 2012a. Pasture production from a long-term fertiliser trial under irrigation. New Zealand Journal of Agricultural Research 55: 105-117.

Smith, L.C.; Orchiston, T.; Monaghan, R.M.; 2012 b. The effectiveness of the nitrification inhibitor dicyandiamide (DCD) for mitigating nitrogen leaching losses from a winter grazed forage crop on a free draining soil in Northern Southland. Proceedings of the New Zealand Grasslands Association 74: 39-44.

Widdup, K.H.; Ryan, D.L. 1992. Forage potential of wild populations of perennial ryegrass collected from southern New Zealand farms. Proceedings of the New Zealand Grasslands Association 54: 161-166. 
